drawn. The patient's head is fixed in the usual manner for microscopical examination and the illumination adjusted. All that remains to be done is to focus the desired portion of the eye in the microscope, remove the filter from the lamp, and make the exposure.

By this arrangement one can obtain with certainty and ease excellent photographs enlarged either 1.7 or 4.1 diameters-the latter by using A2 objectives. With the fourfold magnification even dark brown irides are clearly shown in sufficient detail (see Fig. 3). Using the A2 objective, the 6 by $6 \mathrm{~cm}$. plate is not large enough to reproduce the whole eye and its appendages, but this magnification is very valuable when dealing with minute changes on the bulbus oculi, specially on the cornea, iris, and pupil, which cannot be made out with the usual magnifications. The camera mounting does not interfere with the use of the corneal microscope for other purposes and in any case it may easily be removed. In the same way the Zeiss lamp can be used either alone or in combination with other instruments.

It is considered that the above described apparatus has several advantages over the Lenz camera and specially in that perfectly sharp fourfold magnified photographs can be obtained with ease and certainty; moreover, the apparatus is comparatively cheap.

\title{
REFERENCES
}

1. Lenz.-Klin. Monatsbl.f. Augenheilk., Vol. LXXII, p. 33, 1924.

2. Druener.-Zeitschr. f. wiss. Mikroskop., Vol. XVII, p. 281, 1900 ; Klin. Monatsbl. f. Augenheilk., Vol. LXXII. p. 509, 1924 ; and Vol. LXXIII, p. 311, 1924.

\section{OBSERVATIONS ON THE HYDROGEN ION CONCEN- TRATION IN THE VITREOUS BODY OF THE EYE WITH REFERENCE TO GLAUCOMA}

\author{
BY
}

\section{Dr. Anton GaLA}

ASSISTANT PHYSICIAN, CLINIC OF OPHTHALMOLOGY, BRATISLAVA, CZECHOSLOVAKIA

THE physico-chemical conditions of the vitreous body and their alterations under pathological conditions are almost unknown. As human material is scarcely to be obtained in the requisite quantity without injury to the eye, the existing scant knowledge is founded chiefly on animal observations. This is specially true with regard to the pathogeny of glaucoma. Fischer ${ }^{(1)}$ attempted to explain this condition, but on somewhat slender grounds, as an oedema determined by a disturbance of the acid-base equilibrium in the vitreous body due to an increase in the acid content of the 
eye media. Meesmann ${ }^{(2)}$ examined the aqueous humour from this point of view and found its $\mathrm{Ph}$ increased, but he supposed the heightened tension of the eye to be brought about by constriction of its efferent vessels, the vitreous remaining inactive. The present observations have been directed to the estimation of the hydrogen ion concentration of the vitreous body in various cases of primary and secondary glaucoma and in a number of controls.

The hydrogen ion concentration has been estimated by the Michaelis ${ }^{(3)}$ colour indicator method, unbuffered and using $\mathrm{m}$-nitrophenol as the indicator. The necessary quantity of vitreous was aspirated from the eye by a sterile dry syringe and an accurately measured quantity of 0.5 c.c. was placed in a Jena glass test-tube. To this was added 0.3 c.c. of 0.3 per cent. m-nitrophenol, and physiological saline to make up 3 c.c., the test-tube being then closed with a paraffined rubber stopper. The tint of this solution was measured in a Walpole's comparator against a series of standard tints as described by Michaelis, and the $\mathrm{Ph}$ calculated by the formula $\mathrm{Ph}=\mathrm{Pk}+\log \frac{\mathrm{b}}{1-\mathrm{b}}$ where $\mathrm{b}$ is the degree of colouring (Farbgrad Michaelis).

The results of these observations are given in the accompanying tables. From Table $\mathrm{A}$ it is seen that in five cases (both eyes examined in Case 4) without glaucoma the $\mathrm{Ph}$ has been found to vary from 7.40 to $\pi .52$, the average being 7.47 . Observations on the normal eyes of healthy rabbits have shown the $\mathrm{Ph}$ to lie within the same limits and these observations are in agreement with those of Hertel ${ }^{(4)}$ and Meesmann ${ }^{(2)}$ for the aqueous humour of the anterior chamber, although the protein content of the vitreous is higher. Table B shows that in four cases (Case 2 examined three times) of secondary glaucoma the $\mathrm{Ph}$ varied from 7.39 to 7.60 , the average being 7.53 .

TABle A. Controls.

\begin{tabular}{|c|c|c|c|c|c|}
\hline Case & Diagnosis & State of eye & $\begin{array}{c}\text { Tension } \\
\text { mms. Hg. }\end{array}$ & $\mathrm{Ph}$. & Remarks \\
\hline 1 & Atrophia n. optici & Not in jected & 18 & 7.44 & - \\
\hline 2 & Degen. pigm. ret. & " & 21 & 7.50 & - \\
\hline 3 & Atrophia n. optici & , & 21 & 7.44 & - \\
\hline 4 & Atroph. $\int R$. eye & "' & 26 & 7.50 & - \\
\hline & $\begin{array}{ll}\text { n. opt. } & \text { L. eye }\end{array}$ & ", & 26 & 7.52 & - \\
\hline \multirow[t]{2}{*}{5} & Phthisis bulbi $\quad \ldots$ & Injected & 10 & 7.40 & - \\
\hline & & Average & $\mathrm{Ph}$. & 7.47 & - \\
\hline
\end{tabular}


Table B. Secondary Glaucoma.

\begin{tabular}{|c|c|c|c|c|c|}
\hline Case & Diagnosis & State of eye & $\begin{array}{l}\text { Tension } \\
\text { mms. Hg. }\end{array}$ & $\mathrm{Ph}$. & Remarks \\
\hline 1 & $\begin{array}{l}\text { Le u com a corn. } \\
\text { adher. }\end{array}$ & $\begin{array}{l}\text { Injected very } \\
\text { little }\end{array}$ & 51 & 7.57 & $\begin{array}{l}14 \text { day s a f ter } \\
\text { iridect. antigl. }\end{array}$ \\
\hline 2 & Luxatio L. in. vitr. & Injected & 51 & 7.54 & Untreated \\
\hline & & " & 60 & $\begin{array}{l}7.60 \\
7.52\end{array}$ & $\begin{array}{l}7 \text { days after first } \\
\text { aspiration of vit- } \\
\text { reous } \\
7 \text { days after second }\end{array}$ \\
\hline 3 & $\begin{array}{l}\text { Le uc om a corn. } \\
\text { adher. }\end{array}$ & $\begin{array}{c}\text { Greatly in- } \\
\text { jected }\end{array}$ & 44 & 7.39 & $\begin{array}{l}7 \text { days after cyclo- } \\
\text { dialysis of } \\
\text { Heine }\end{array}$ \\
\hline \multirow[t]{2}{*}{4} & \multirow[t]{2}{*}{ Staphyloma corneae } & ," & 45 & 7.57 & 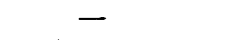 \\
\hline & & Average & $\mathrm{Ph}$. & 7.53 & \\
\hline
\end{tabular}

Table C. Primary Glaucoma.

\begin{tabular}{|c|c|c|c|c|c|}
\hline Case & Diagnosis & State of eye & $\begin{array}{c}\text { Tension } \\
\text { mms. Hg. }\end{array}$ & $\mathrm{Ph}$. & Remarks \\
\hline 1 & G1. Infl. chron. ... & Not injected & 45 & 7.64 & - \\
\hline 2 & , $\quad .$. & , & 50 & 7.60 & - \\
\hline \multirow[t]{4}{*}{3} & , $\quad$ R. eyc & ", & 73 & 7.57 & $\begin{array}{l}\text { A year after iridect. } \\
\text { antigl. }\end{array}$ \\
\hline & " $\quad$, L. eye & " & 63 & 7.54 & " , , \\
\hline & " R. ey & ", & 60. & 7.60 & $\begin{array}{l}14 \text { days after first } \\
\text { aspiration }\end{array}$ \\
\hline & " & $\begin{array}{l}\text { Very little in } \\
\text { jected }\end{array}$ & 55 & 7.56 & $\begin{array}{l}21 \text { days after first } \\
\text { aspiration }\end{array}$ \\
\hline 4 & " & $\begin{array}{l}\text { Slightly in- } \\
\text { jected }\end{array}$ & 63 & 7.52 & - \\
\hline 5 & , & Injected & 51 & 7.57 & - \\
\hline \multirow[t]{2}{*}{6} & \multirow[t]{2}{*}{ Gl. infl. acutum ... } & $\begin{array}{c}\text { Greatly in- } \\
\text { jected }\end{array}$ & 83 & 7.56 & - \\
\hline & & Average & $\mathrm{Ph}$. & 7.57 & \\
\hline
\end{tabular}

Most interesting, however, are the results in six cases of primary glaucoma (Case 3 examined four times); Table $\mathrm{C}$ shows that here the $\mathrm{Ph}$ is definitely higher not only than in a normal eye but than in an inflamed eye. The $\mathrm{Ph}$ varies from 7.52 to 7.64 , the average being 7.57. This increase in the alkalinity of the vitreous can hardly be regarded as a passive change and will not be without 
influence on its volume. For, from the physico-chemical point of view the vitreous body belongs to the hydrophil emulsoids and it is known that the degree of swelling of such emulsoids is dependent, among other factors, chiefly on the acid-base equilibrium and that, within certain limits, the lower the hydrogen ion concentration the greater is the swelling. It would seem, therefore, that in the observed increased alkalinity of the vitreous body lies a possible explanation of the increased intraocular tension in glaucoma.

One of the difficulties of the currently accepted explanation of primary glaucoma, as due to diminished outflow through the canal of Schlemm, is that the anterior chamber is not deeper as would be expected but is actually shallower than normal. On the present view, however, a shallow anterior chamber would follow as a natural result from the presence of a swollen vitreous, the swelling being due to an alteration of its acid-base equilibrium, not, however, in the direction of increased acidity as put forward by Fischer, but in the direction of increased alkalinity.

As regards the cause of the disturbance no explanation can be offered at present but it is suggested that more attention should be paid to the blood in glaucoma.

\section{REFERENCES}

1. Fischer.-Pflüger's. Arch. f. Physiol., Vol. CXXVII, pp. 1-3, 1909.

2. Meesmann.-Arch. f. Augenheilk., Vol. XCIV, p. 115, 1924.

3. Michaelis u. Gyemann.-Biochem. Zeitschr., Vol. CIX, p. 165, 1920.

4. Hertel.-Arch.f. Ophthal., Vol. CV, p. 421, 1921.

\section{CHANGES IN REFRACTION ASSOCIATED WITH TRANSIENT GLYCOSURIA}

BY

\section{A. J. Ballantyne \\ GLASGOW}

As an addendum to the important paper of Dr. W. Stewart DukeElder in the April number of the British Journal of Ophthalsologiy, the following case may be of interest.

Mr. D.F.C., aged 58 years, a business man of heavy build, came under my care in March, 1923, owing to a defect in the vision of his left eye which his optician was unable to correct with glasses. He had been aware of a defect in this eye for twenty years. Vision (March, 1923) was R. $=5 / 9, \mathrm{~L} .=5 / 12$, and with correction, $5 / 5$ and $5 / 6$. He gave a "gouty" history, and his eyelids presented several chalazia and conjunctival lithiases. On ophthalmoscopic examination the right eye was found to be normal except for the 